\title{
Sprawozdanie z prac w Bibliotece Polskiej w Paryżu w 2018 r.
}

W trakcie kolejnego pobytu w Bibliotece Polskiej w Paryżu w dniach 1-27 października 2018 r. kontynuowałem rozpoczęte w ubiegłym roku opracowywanie zespołu akt wytworzonych przez reaktywowane w 1946 r. Polskie Towarzystwo Historyczno-Literackie w Paryżu ${ }^{1}$.

Prowadzone prace dotyczyły archiwaliów z utworzonych wcześniej dwóch serii aktowych:

1. materiałów związanych z corocznie organizowaną przez Towarzystwo od XIX w. (z przerwą w okresie II wojny światowej) pielgrzymką Polaków do podparyskiej miejscowości Montmorency (ostatnie lata życia spędzili w niej Julian Ursyn Niemcewicz i gen. Karol Kniaziewicz, tam pochowani) i obchodzonymi w tamtejszej kolegiacie św. Marcina i na cmentarzu Champeaux uroczystościami o charakterze religijno-patriotycznym oraz dokumentów dotyczących grobu zbiorowego Towarzystwa znajdującego się na tym cmentarzu. W trakcie prac skompletowałem niemal całą serię tych akt, tworząc 14 j.a. (o objętości $0,48 \mathrm{mb}$ ).

2. akt w sprawach darów lub depozytów przekazanych przez Polaków żyjących na emigracji do zbiorów Towarzystwa Historyczno-Literackiego i Biblioteki Polskiej w Paryżu w postaci muzealiów (obrazy, meble, grafiki, przedmioty użytku codziennego), rękopisów, książek i czasopism. Z tych materiałów utworzona została seria licząca 29 j.a.(o objętości $0,45 \mathrm{mb})$. Ze względu na stosunkowo duże rozmiary dokumentacji prace nad tą serią wymagają kontynuacji.

Oprócz tego skatalogowałem dziesięć tomów o objętości 0,27 mb protokołów z walnych zebrań członków i posiedzeń Rady Towarzystwa z lat 1946-1997 (księgi te zostały założone w związku z wymogami prawa francuskiego - mają one odpowiedniki w postaci osobnej serii akt luźnych).

Ponadto 26 października, w przedostatnim dniu pobytu, uczestniczyłem w sesji naukowej z okazji 180-lecia istnienia Biblioteki Polskiej w Paryżu, zorganizowanej pod patronatem Prezydenta Republiki Francuskiej i Prezydenta Rzeczypospolitej Polskiej przez Towarzystwo, przy wsparciu Stacji Naukowej w Paryżu Polskiej Akademii Nauk. W trakcie tej konferencji wygłosiłem w języku francuskim dwa referaty dotyczące działalności wieloletniego dyrektora Biblioteki Franciszka Pułaskiego (1926-1956) oraz kustosza zbiorów Biblioteki i Muzeum Adama Mickiewicza Ireny Gałęzowskiej (pracowała w Bibliotece w latach 1929-1977), przygotowane w oparciu o archiwalia inwentaryzowane i opracowywane w trakcie wcześniejszych wyjazdów do Biblioteki.

Wiestaw Filipczyk Archiwum Narodowe w Krakowie

${ }^{1}$ Por. Wiesław Filipczyk, Sprawozdanie z prac w Bibliotece Polskiej w Paryżu w 2017 r., „Krakowski Rocznik Archiwalny” 2017, t. 23, s. 269-270. 